\title{
Investigating Elite Behavior through Field Experiment in Brazil: do candidates answer more to core or swing voters? ${ }^{1}$
}

\author{
Paolo Spada \\ Ash Center for Democratic Governance and Innovation, Harvard Kennedy \\ School, USA \\ Feliciano de Sá Guimarães \\ Escola Superior de Propaganda e Marketing (ESPM), Brazil
}

\begin{abstract}
This paper explores recent advances in experimental methodology to analyze elite behavior. Using an email experiment conducted in the context of the Brazilian 2008 municipal elections, we studied whether candidates target "swing" or "core" voters during campaigns. Candidates from all parties - 1,000 candidates in all - were contacted by randomly generated citizens who identified themselves as either core or swing voters. Additionally, we randomized senders' past voting behavior and their gender. To identify the baseline answer rate, we employed a placebo treatment with no reference to the elections. Our results show that Brazilian candidates target any sender as long as she identifies herself as a potential voter. Within this general finding, models with city-specific fixed effects indicate that Brazilian politicians tend to target core voters. The paper contributes to the general experimental literature by providing an easily replicable design that can test the behavior of elite interaction with the public. At the same time, the paper extends the literature on core versus swing voters by providing an empirical test that can shed light on the effects of a specific political environment (type of election, voting rule, and party structure), and how it affects the relationship between candidates and voters during elections.
\end{abstract}

Keywords: Experimental analysis, Electoral Studies, Urban Politics, Methodology

1 We would like to thank Luis Schiumerini and Jazmin Sierra for their thoughtful comments and proper review of the paper. We also would like to thank Ernesto Calvo for his comments on one of the first versions of the experiment. The two BPSR anonymous reviewers provided important contributions towards the improvement on the interpretation of the findings. 


\section{Introduction}

The literature on how politicians allocate resources in order to optimize elector-

al performance has generated intense debate in the social sciences. Some lean towards Cox and McCubbins' 1986 model in which politicians allocate resources to core voters (Calvo and Murillo, 2004; Ansolabehere and Snyder 2006; Nichter, 2008; Magaloni et al., 2008; Cox, 2009). Others prefer Lindbeck and Weibull's 1987 model (Schady, 2000; Case, 2001; Dahlberg and Johansson, 2002; Stokes, 2005) where politicians focus on undecided or swing voters.

Empirical tests of the two models using non-experimental methods present mixed results (Schady, 2000; Dahlberg and Johansson, 2002; Calvo and Murillo, 2004; Stokes, 2005; Ansolabehere and Snyder, 2006; Magaloni et al., 2008). Our study is the first to apply a field experiment in order to further test some of the claims in this ongoing debate. Through a modified "email experiment" we implemented a test in order to shed some light on candidate behavior. This article is based on a field experiment conducted in the context of the 2008 Brazilian municipal election. We aim to elucidate if candidates are more responsive to swing or core voters' demands, or if they answer indiscriminately.

It is important to mention that these empirical studies focus on traditional clientelistic practices and distributive politics; they look to understand how resources are allocated to certain group of voters through clientelistic practices. Our paper has a different approach, which is to understand how candidates answer to voters' demands. We want to verify whether politicians target voters trough signaling mechanisms rather than resource distribution. Answering to voters' demands is different from resorting to clientelistic practices. Generally, we are interested in the discussion of distributive politics. However, we tackle it via communication rather than spending or patronage because our research design allows us to better gauge politicians' strategies from that perspective. Therefore the results may shed light on the clientelism agenda because the allocation of candidates' scarce time may mimic the process of allocation of other resources, although this argument cannot be made based on our experiment candidates' use of clientelistic practices towards certain voters. We can argue, however, that candidates have a preference to communicating with voters that present specific ideological characteristics.

Using an experiment design we directly measure the candidates strategies towards voters, while avoiding problems with endogeneity, collinearity, and self-selection of the traditional distributive politics literature. Experiments are complementary to more traditional empirical methods because they have a higher degree of internal validity and ability to derive causal inference, as well as a more precise measurement of the variables of interest (Gerber et al., 2004; Gerber and Green, 2012). 
The logic of the "email experiment" design we propose is quite simple. We measure the probability of a candidate or a candidate's staff to respond to emails sent by different types of voters. During the weeks previous to the election, time is a scarce resource for candidates and staff. If we consider the allocation of time as an "investment", then a candidate seeking to win the election would invest time where he or she expects to obtain the highest return, i.e. the highest probability of gaining a vote. Therefore if the candidates consistently targeted one type of sender it would mean this type of sender was considered on average a better "investment".

Our experimental test is specifically designed to identify systematic patterns in the candidate answering rate. The treatment is the voter type. Some voters identify themselves as loyal supporters that will certainly vote for the candidate (core), while others state that they are undecided (swing). We also employ a "no identification" email, or placebo, in which the sender simply asks a question with no reference to the coming election. This treatment aims to capture the baseline-answering rate to a generic email during the electoral period. Additional treatments investigate the effects of other characteristics of the senders, such as past voting behavior, gender, and profession.

We ran the experiment during the Brazilian municipal elections of October 2008. The unique Brazilian institutional setting was the inspiration for the choice of the Brazilian local election. In Brazilian elections parties often change coalitions, and electors regularly vote on a personal basis. We sent an email to each mayoral candidate in all the cities above 50,000 inhabitants. The email asked if the candidate had the intention to lower the IPTU tax, a local tax on property. A total of 1181 emails were sent, and 1051 responses were obtained. Focusing on the difference between a treatment effect and the placebo effect allows us to safely drop the missing values from the sample. The answer rate of candidates demanded by core voters $(123 / 358=34.3 \%)$ is only slightly higher than the rate for candidates questioned by swing voters $(103 / 340=30.2 \%)$. The senders that did not offer any identification received a significantly lower proportion of answers statistically $(74 / 353=20.9 \%)$. The Brazilian results shows that emails referring to the elections in the subject had a higher probability of being answered, but also that Brazilian politicians, at first glance, seem not to differentiate between swing and core voters when allocating time to answering emails.

With some simple modifications our design can be used to investigate any type of elite interaction with the public. As long as the researcher can alter the signals received by the elite and treatments can be easily hidden among many other similar signals from the public, it is possible to implement an experimental design for studying elite behaviors. 
The article will proceed as follows. Firstly, we will review the political economy literature on politicians' behavior. Secondly, we will describe the design in detail. In conclusion we will propose an experimental research agenda on elite behavior.

\section{The debate on core voters and swing voters}

As mentioned in the introduction, the literature on candidate behavior presents two main models: the Cox and McCubbins (1986) model and the Lindbeck and Weibull (1987) model. For the former, vote-maximizing politicians focus their resources on core constituencies. In this framework, politicians perceive swing voters as a risky investment, while core voters that have declared their preferences are perceived as a safe investment. In addition, politicians seek to prevent voters from abandoning their party. Contrastingly, in Lindbeck and Weibull's framework, money spent on ideologically proximate voters is wasted, since they will vote for the candidate's party regardless. The intuitive logic behind this model is clearly summarized by Stokes (2005: 317):

Voters who are predisposed in favor of a party on partisan or programmatic grounds cannot credibly threaten to punish their favored party if it withholds distributive rewards. Therefore the party should not waste rewards on them.

These initial papers generated equilibrium results in which parties focused all their resources either on swing or core voters (Cox and McCubbins, 1986 and Lindbeck and Weibull, 1987). Subsequent papers expanded this analysis to allow parties and candidates to adopt additional strategies. The current literature focuses on four strategies; rewarding loyalists (core voters who will turnout); vote buying (swing or opposition voters that will turnout); turnout buying (a core voter that may not turnout) and double persuasion (swing or opposition voters that may not turnout) (Nichter, 2008). Interestingly, while the earlier literature had a clear equilibrium prediction, the more recent literature does not present definite results. According to the modern literature, in equilibrium we should observe different strategy portfolios depending on the characteristics of the polity (e.g. voter loyalty, collective action costs, propensity to turnout and existence of a party machine) that influence the relative payoff of each strategy. Most current papers still propend towards one main strategy, but contend that the party would also follow others.

Nichter (2008) and Cox (2009) have strengthened the "core vote model" by relaxing some of its assumptions. Nichter questions the assumption that all voters turnout to vote as some may abstain. Consequently, the party machine has to spend resources among proximate voters in order to buy turnout, instead of simple vote buying. In this model, politicians have to invest resources to convince a latent core constituency to go to the polls. 
Similarly, Cox notes that models on distributive politics focus solely on persuasion. Once coordination (lowering similar competitors in the ballot) and mobilization (taking voters to the polls) are included, it is possible to confirm that parties allocate benefits to individuals who can provide coordination and mobilization services, rather than brokers who are experts at identifying swing voters (Cox, 2009). What Nichter (2008) and Cox (2009) show is that the "core vote model" can be reinforced by questioning its unidimensionality. These authors demonstrate that it is possible to strengthen the model by refining voter types and politicians' behaviors.

In a more recent paper, Dunning and Stokes (2008) seek to bridge the gap between the swing and core voter models. They demonstrate that Nichter (2008) and Cox (2009) are correct in questioning the fact that not all voters actually vote, but they argue that these critics have not gone as far as they could in challenging the unidimensionality of the "core vote model". They present a full two-dimensional model. In their view, a party chooses how to distribute resources based on two dimensions of voter difference: propensity to vote or abstain and ideological position. The results are three-fold. Firstly, under general conditions parties tend to buy both votes and turnout. Secondly, among supporters who go to the polls anyway (non-abstainers) the party is better off targeting swing and weakly opposed voters. When it comes to non-abstainers, the machine can gain additional votes by spending resources on swing voters only. Thirdly, among potential voters (those who may turn out if offered a benefit) the party will target supporters. In other words, the party will try to take to the polls only those who are likely to vote for it.

As was mentioned in the introduction, empirical studies on the two models based on non-experimental methods have had so far mixed results. There are empirical records supporting the "swing voter model" (Schady, 2000; Dahlberg and Johansson, 2002) and others more consistent with the "core voter model" (Calvo and Murillo, 2004; Ansolabehere and Snyder 2006, and Magaloni et al., 2008). In order to identify the voter groups (swing or core), these studies employ either surveys estimating the distribution of political preferences among voters (Dahlberg and Johansson, 2002; Stokes, 2005), or aggregate voter returns biased by clientelistic actions of party patrons (Schady, 2000; Calvo and Murillo, 2004, 2009; Magaloni et al., 2008).

As previously stated, these empirical studies are focused on distributive politics (clientelistic practices). They attempt to understand how different clientelistic practices work in different political environments, especially resource allocation towards a group of voters. This paper has a different goal, which is to understand how candidates answer to voters demands. Answering to voter demands is clearly different than resorting to clientelistic practices, although the results might shed light on the topic of clientelism due to the fact 
that the allocation of candidates' scarce time might mimic the allocation process of other resources.

Additionally, it is important to keep in mind that our paper employs an ideological definition of core and swing voters. This is different from some of the definitions encountered in the relevant literature. As Calvo and Murillo (2004) note, among the different definitions some authors highlight an adherence dimension, for example a special identity between the party and a defined group of voters (Cox and McCubbins, 1986). Others stress the loyalty of voters, such as the ideological proximity to a party's political platforms (Stokes, 2005). Some works emphasize the physical proximity to party networks (Calvo and Murillo, 2004), and others the relative riskiness of voters (Diaz-Cayeros, 2008). This can be simplified into three main definitions; (a) Core voters have an ideological preference toward a party; (b) Core voters are those that parties may target more easily or cheaply (i.e. the leaky bucket is less leaky for them) and (c) Core voters are less risky (due to their steady and certain behavior through time) (Calvo and Murillo, 2009). However, mathematically the three concepts lead to similar mechanics of altering the expected net-cost of buying out voters. Thus, the current generation of models cannot distinguish among them. It is also unclear if our experiment can clear these differences out.

In this article, following Stokes 2005, we define core voters as loyal voters whose ideological proximity to a party's political position prevents defection based on tactical redistribution of benefits by other parties. Our test explores the effect of the ideological position of voters (core and swing) on candidates allocation of time and resources. Apparently, this core voter definition should only be tested in countries where core voters have partisan or programmatic (not clientelistic) links to parties. While weak partisan identities would render Brazil an inappropriate setting to conduct the experiment, the fact that we are manipulating voters ideological positions and that the communication is individual should enhance the message credibility in the minds of candidates (Samuels and Zucco, 2012).

The next section explores the experiment in detail. The same design may be employed to test the reaction of candidates to voters that are more or less proximate, or their riskiness, but in the current implementation we focus purely on ideology and propensity to vote.

\section{The experimental design}

The "email experiment" design is a modification of the "cv experiment". In a "cv experiment" different applications (e.g. CVs and housing applications) are sent to multiple recipients to see if they respond in differently depending on the characteristics of the 
sender, such as gender, race, and ethnicity (e.g. Firth 1981; Weichselbaumer 2003; Oreopoulos, 2009).

In the "contacting the candidate" design the recipient is not an employer but a candidate running in political elections. The treatments randomly alter the characteristics of the sender to investigate the behavior of aspiring politicians during electoral campaigns. The variables that can be easily recorded by the researcher are the answer rate, the content of the answer, and the time taken to receive an answer. In the examples reviewed we will focus only on the answer rate. When using emails as media, as in our implementations, failure to contact is easily identified, and usually comes with an identification code (e.g. a spam filter blocked the email, the mailbox was full or the email did not exist).

\section{The experimental design: the Brazilian municipal elections of 2008}

The Brazilian electoral system for city Assemblies is rather unique: while an open list allows voters to cast a vote for an individual candidate, it also gives them the option of voting exclusively for the party (voto de legenda). Mayors are chosen in single member districts, through a plurality system in cities with a population of less than 200,000 and a majoritarian run-off system in cities over that threshold. The Brazilian literature shows that politicians' personal reputation is key to shaping voters' preferences (Nicolau, 2002; Carreirão and Kinzo, 2004; Carreirão, 2007). Parties constantly struggle to establish themselves and retain a set of loyal supporters. More importantly, the highly fragmented party system induces the creation of large government coalitions (Nicolau, 1996; Amorim Neto, 1998). It is very common to observe traditional leftist parties, such as the Workers' Party (Partido dos Trabalhadores) and the Socialist Party (Partido Socialista Brasileiro) establishing coalitions with right wing parties, especially at a local level. In such a scenario, it is more difficult for Brazilian voters to differentiate left from right and vice versa (Ames and Smith, 2010). As we will hypothesize in the conclusion, another possible consequence is that this very unique institutional setting makes it more difficult for Brazilian candidates to retain voter support between elections.

The experiment was conducted on September $22^{\text {nd }} 2008$, two weeks before the $\mathrm{Mu}-$ nicipal elections in Brazil. All emails were sent in one day using newsletter software eliminating the possibility that an external shock would change the answer rate of different days. We used 18 aliases, 9 males and 9 females. The structure of the email was identical for all name.surname@gmail.com. We randomized the most common names and surnames found on a Brazilian website. In the event that the email would not be available we added a number after the surname. 
The experiment focused on the mayoral candidates in every city with more than 50,000 inhabitants ( $~ 550$ cities). Candidates' emails were obtained from the Brazilian Electoral Tribunal, with access to a list containing the majority of the candidates. The number of candidates varies between two and more than 10 per city, but not all candidates have an email account. Thus in our sample the number of candidates varies between 1 and 7.

A total of 1181 emails were sent. We excluded 173 emails from the sample: 103 due to miscoding of the email and 70 because of sending duplicate emails to the same recipient. Finally, 7 emails arrived after the Election Day. The total available sample is 1008.

An interesting characteristic of this experiment is that it allows recording contact failures and analyzing their reasons (e.g. the email account does not exist, the email account is full). Probably due to the nature of the experiment we had very few treatment failures. Candidates monitor their email accounts frequently and thus no email bounced back due to a full email account. Given that we are studying the difference between the treatment effect and the placebo effect, and we do not have a traditional control group, we can simply drop these missing values or contact failures from the sample. Thus the results we present only apply to politicians who have an active email account.

Given that the Brazilian experiment was conducted during a municipal election, it was necessary to find a baseline question concerning local politics. One important and constant issue of electoral campaigns in Brazilian cities is the reduction of taxes, in particular the reduction of real estate tax (IPTU). Therefore each alias asked the same question regarding the reduction of IPTU. The reduction of taxes is usually a non-neutral question, because it is more strongly advocated by right-wing coalitions. The presence of a placebo treatment, in which the senders did not provide any identification, addresses this problem. A comparison between the answer rates in the treatment groups and the placebo illuminates the potential bias induced by the question itself. The placebo group identifies the baseline effect of the message, which is an average of all the potential effects of the elements of the email that were not considered as a treatment (the question itself, the specific name of the sender, the email provider and the time of the day the email was received).

Typically candidates for the mayor office in Brazil are supported by large electoral coalitions. These coalitions vary in composition dramatically. Parties that are allied in one city are often running in opposite coalitions in other cities. In addition, parties switch coalitions over the years in the same city. For these reasons the concepts of left and right are difficult to apply in Brazil at the municipal level. Therefore, we have phrased the treatment to investigate past support. Some senders declared they have "always voted for the party of the candidate". Others declared they have "never voted for the party of the candidate". Finally, a group of senders did not provide any information regarding past support. 
We also investigated the effect of gender. The treatment scheme was therefore $3 \times 3 \times 2 \times 2$. The following three examples exemplify some of the treatments. The original text was in Portuguese.

Example 1: Swing; Right; Entrepreneur; Male

SUBJECT: A question from an undecided voter

How do you do? My name is $B$ and in the past I have always voted for your party. In this election I am still undecided and I am not sure if I will vote for you or for another candidate. I have a question regarding the IPTU. In the past few years I have paid a lot of IPTU and I would like to know if you will lower the tax rate. I believe that this could increase the tax revenue of the city. Do you have any proposals concerning this matter?

Best Regards

Mr. B

Small Entrepreneur

Example 2: Core; placebo; placebo; Female

SUBJECT: A question from one of your supporters

How do you do? My name is $C$. In the next election I will vote for you. I have a question regarding the IPTU. In the past few years I have paid a lot of IPTU and I would like to know if you will lower the tax rate. I believe that this could increase the tax revenue of the city. Do you have any proposals concerning this matter?

Best Regards

Ms. C

Example 3: placebo; placebo; placebo; Female

SUBJECT: A question

How do you do? My name is B. I have a question regarding the IPTU. In the last few years I have paid a lot of IPTU and I would like to know if you will lower the tax rate. I believe that this could increase the tax revenue of the city. Do you have any proposals concerning this matter?

Best Regards

Ms. B

Additionally, in order to capture the possibility that the political dynamic in cities with more than 200,000 registered voters may differ from the smaller cities (between 50,000 and 200,000 registered voters) we have stratified the treatments by electoral system. Electoral rules in Brazil depend on the size of the municipality. In cities with more 
than 200,000 registered voters there is a second round (run off). That is, if in the first round a candidate does not receive more than $50 \%$ of the valid votes, a second round is held a couple of weeks later. In cities with less than 200,000 registered voters, the candidate with the most votes wins, regardless of the $50 \%$ margin. In Brazil voting is compulsory, but the law is not stringently enforced and there are still a considerable number of people that do not vote. In our sample 269 candidates were running in cities with a tworound system, while the remaining 789 were running in smaller cities with a single round.

\section{The results}

289 candidates responded to the email. This corresponds to $28.7 \%$ of the 1,008 contacts. Candidates from cities with more than 200,000 registered voters and, consequently, with a run-off election answered slightly more than candidates from smaller cities $(33.4 \%$ vs. 27\%). Table 1 summarizes the design and displays the answer rate for each treatment.

Core voters received more answers $(123 / 359=34.3 \%)$ than swing voters $(92 / 294=31.3 \%)$, but this difference is not statistically significant. Voters in the "no identification" group receive significantly fewer replies than both groups $(74 / 355=20.8 \%)$. A t-test of difference in means between the no identification group and the swing voters group (-10.4\%) always rejected the null. The 95\% confidence interval on the difference is contained between $-3 \%$ and $-17 \%$. Additionally, the difference between the no identification group and the core treatment group (-13.4\%) is significantly different from zero, while the $95 \%$ confidence interval on the difference is contained between $-6.9 \%$ and $-19.9 \%$.

Table 1. Answer rate

\begin{tabular}{lllll}
\hline \multicolumn{2}{l}{ Sender's type } & & & \\
\hline Sender's Voting history & No identification & Core & Swing & Total \\
\hline Undeclared & $20 / 119$ & $43 / 117$ & $32 / 122$ & $95 / 348$ \\
& $(16.8 \%)$ & $(36.7 \%)$ & $(28.5 \%)$ & $(27.3 \%)$ \\
\hline Supporter in the previous elections & $23 / 117$ & $40 / 120$ & $19 / 56$ & $82 / 293$ \\
& $(19.7 \%)$ & $(33.3 \%)$ & $(33.9 \%)$ & $(27.9 \%)$ \\
\hline Non Supporter in the previous election & $31 / 119$ & $40 / 122$ & $41 / 126$ & $112 / 367$ \\
& $(26 \%)$ & $(32.8 \%)$ & $(32.5 \%)$ & $(30.5 \%)$ \\
\hline Total & $74 / 355$ & $123 / 359$ & $92 / 294$ & $289 / 1008$ \\
& $(20.8 \%)$ & $(34.3 \%)$ & $(31.3 \%)$ & $(28.7 \%)$ \\
\hline
\end{tabular}

The lower answer rate to senders in the no identification group could be due to the fact that the subject of the email ("a question") contains no reference to the election, while 
the two other groups contain explicit references ("a question from one of your supporters" and "a question from an undecided voter").

On inspection of Table 1 two things stand out. Firstly, among the voters with no declared voting history, those that sent a core voter message received a higher answer rate $(36.7 \%)$ than those that sent a swing message (28.5\%). The usual battery of tests reveals that we cannot rule out the possibility that the difference in the answer rate is zero. The one tail t-test rejects the null at the $10 \%$ level $(\mathrm{Pr}=0.094)$, but the one tail Fisher exact test does not reject the null $(\mathrm{Pr}=0.119)$. Thus there is only a weak indication that the core group mean is larger than the swing group mean. The $95 \%$ confidence interval on the difference is contained between $-4 \%$ and $20 \%$.

If we now turn our attention to the first column we can see that among the voters that sent a message with no identification, those that sent a "non supporter in the past" message received a higher answer rate (26\% vs. $19.7 \%)$. This difference is not statistically significant in our sample. When considering the treatment gender and the treatment "small entrepreneur" and all the possible interactions we find no effect.

\section{The Brazilian case: main considerations}

The results of our analysis point out that Brazilian candidates did not target either swing or core voters specifically. They instead targeted any sender that could have been a potential voter. As illustrated in Table 2 , those senders that did not clearly identify themselves as potential voters received on average $10 \%$ less answers:

Table 2. Answer rate in the Brazilian Experiment

\begin{tabular}{|l|l|l|}
\hline Sender's type & \multicolumn{2}{|l|}{} \\
\hline No identification & Potential voter (Core or Swing) & Total \\
\hline $74 / 355$ & $215 / 653$ & $\begin{array}{l}289 / 1008 \\
(28.7 \%)\end{array}$ \\
$(20.8 \%)$ & $(32.9 \%)$ & \\
\hline
\end{tabular}

These results could reflect either the personalistic nature of Brazilian local elections (Nicolau, 2002; Carreirão and Kinzo, 2004; Carreirão, 2007), the smaller amount of votes required for election in small cities, or concerns regarding voters' turnout. Therefore, to shed additional light on the Brazilian case we present a multivariate analysis in Table 3 that controls pre-treatment covariates that might correlate with the answer rate. We also show a Linear Probability model corrected for heteroskedasticity. To control unobserved municipality characteristics we use city-specific dummies. The dependent variable is the 
rate of answers to the senders. The placebos for the first and second treatment group are the baseline reference, thus the first four coefficients must be interpreted as the difference between the treatment effect and the placebo/no identification email.

The first column is our basic model using only the experimental treatments. As expected the model recovers the treatment effects we discussed in the previous section. In the second column we observe that when introducing city-specific fixed effects, the swing coefficient becomes insignificant; the model does not detect any statistical difference between the answer rate to senders that identified themselves as swing voters or that did not provide any identification. The core coefficient decreases instead, but remains positive and statistically significant $(+10 \%$, with a p-value of 0.017$)$. The $95 \%$ confidence interval for this estimate is contained between $1.8 \%$ and $18.3 \%$. The other treatments (past voting behavior, the sender identifying themselves as a small entrepreneur) are not statistically significant, apart from "Male". If the sender identified themselves as a male, the probability of receiving an answer was slightly lower. This result is borderline significant at the $10 \%$ level, and the 95\% confidence interval for this estimate is contained between $-12 \%$ and $0.9 \%$.

The third column introduces three additional controls. The first ("Education") is a measure of the education of the candidate; it assumes value 1 if the candidate has completed high school. The second is the age of the candidate, while the third identifies incumbents that were running for re-election. While education has no significant impact on the answer rate, the age of the candidate has a small negative impact and the incumbency has the largest negative effect on the probability of receiving an answer. The core coefficient remains positive and statistically significant $(+10.7 \%$ with a p-value of 0.011$)$. The $95 \%$ confidence interval suggests a slightly higher value contained between $2.5 \%$ and $18.9 \%$.

Finally, in the fourth column we introduce a measurement of the political stance of the coalition supporting the candidate. Due to the extreme regional differences and the nature of municipal politics, coalitions are rather fluid in Brazil. Our simple classifications of Left, Mixed and Right are rather crude. Therefore we present these results separately, and we caution the reader to take them cum granu salis. From column 4 we can see that the core treatment effect remains strongly significant and around 10\%, with a 95\% confidence interval contained between $2.5 \%$ and $18.5 \%$. The effect of incumbency remains most prominent, $-22 \%$, with a 95\% confidence interval contained between $-32 \%$ and $11.8 \%$. Finally, the age of the candidate and the leaning toward the extreme right of the candidate's coalition have a minor negative effect on the answer rate. These effects have a weak significance. The 95\% confidence interval for Age is contained between $-0.07 \%$ and $+0.001 \%$, while the one for the leaning of the coalition toward the extreme right is contained between $-7.5 \%$ and $+0.01 \%$. 
Table 3. Multivariate Analysis, Brazil 2008, Municipal Elections

\begin{tabular}{|c|c|c|c|c|}
\hline \multicolumn{5}{|c|}{ Dep. Variable: receiving an answer } \\
\hline & LPr baseline & $\mathrm{LPr}$ & $\mathrm{LPr}$ & $\mathrm{LPr}$ \\
\hline Swing & $\begin{array}{l}0.101 * * * * \\
(2.89)\end{array}$ & $\begin{array}{l}0.060 \\
(1.33)\end{array}$ & $\begin{array}{l}0.058 \\
(1.28)\end{array}$ & $\begin{array}{l}0.051 \\
(1.14)\end{array}$ \\
\hline Core & $\begin{array}{l}0.131^{* * * *} \\
(3.97)\end{array}$ & $\begin{array}{l}0.101^{* * *} \\
(2.40)\end{array}$ & $\begin{array}{l}0.11^{* * * * *} \\
(2.68)\end{array}$ & $\begin{array}{l}0.105^{* * * *} \\
(2.58)\end{array}$ \\
\hline Past Supporter & $\begin{array}{l}0.021 \\
(0.58)\end{array}$ & $\begin{array}{l}0.044 \\
(0.97)\end{array}$ & $\begin{array}{l}0.048 \\
(1.09)\end{array}$ & $\begin{array}{l}0.047 \\
(1.05)\end{array}$ \\
\hline Past Opposer & $\begin{array}{l}0.04 \\
(1.16)\end{array}$ & $\begin{array}{l}0.06 \\
(1.37)\end{array}$ & $\begin{array}{l}0.061 \\
(1.27)\end{array}$ & $\begin{array}{l}0.061 \\
(1.27)\end{array}$ \\
\hline Male & $\begin{array}{l}-0.035 \\
(-1.25)\end{array}$ & $\begin{array}{l}-0.058 * \\
(-1.69)\end{array}$ & $\begin{array}{c}-0.053 \\
(-1.55)\end{array}$ & $\begin{array}{l}-0.055 \\
(-1.61)\end{array}$ \\
\hline Small Entrepreneur & $\begin{array}{l}0.027 \\
(0.85)\end{array}$ & $\begin{array}{l}0.066 \\
(1.57)\end{array}$ & $\begin{array}{l}0.067 \\
(1.63)\end{array}$ & $\begin{array}{l}0.068^{*} \\
(1.65)\end{array}$ \\
\hline Education & & & $\begin{array}{l}0.003 \\
(0.008)\end{array}$ & $\begin{array}{l}-0.003 \\
(-0.001)\end{array}$ \\
\hline Candidate Age & & & $\begin{array}{l}-0.004^{* * * *} \\
(-2.42)\end{array}$ & $\begin{array}{l}-0.003^{*} \\
(-1.91)\end{array}$ \\
\hline Incumbent & & & $\begin{array}{l}-0.23^{* * * * *} \\
(-4.39)\end{array}$ & $\begin{array}{l}-0.22 * * * * \\
(-4.19)\end{array}$ \\
\hline Coalition & & & & $\begin{array}{l}-0.037^{*} \\
(-1.96)\end{array}$ \\
\hline District Dummies & & Included & included & Included \\
\hline Constant & $\begin{array}{l}0.194^{* * * * *} \\
(4.85)\end{array}$ & $\begin{array}{l}0.194^{* * * * *} \\
(3.83)\end{array}$ & $\begin{array}{l}0.43^{* * * * *} \\
(3.91)\end{array}$ & $\begin{array}{l}0.119 \\
(1.42)\end{array}$ \\
\hline Joint Test & $\begin{array}{l}\mathrm{F}(6 ; 1001)=3.72 \\
0.001\end{array}$ & $\begin{array}{l}\mathrm{F}(6 ; 426)=2.03 \\
0.06\end{array}$ & $\begin{array}{l}\mathrm{F}(9 ; 426)=4.49 \\
0.00\end{array}$ & $\begin{array}{l}\mathrm{F}(9 ; 426)=5.69 \\
0.00\end{array}$ \\
\hline $\begin{array}{l}\text { Groups } \\
\mathrm{N}\end{array}$ & 1008 & $\begin{array}{l}427 \\
1008\end{array}$ & $\begin{array}{l}427 \\
1008\end{array}$ & $\begin{array}{l}427 \\
1008\end{array}$ \\
\hline $\begin{array}{l}\text { The first four coeffic } \\
\text { ences from the no id } \\
\text { "Education" is a dun } \\
\text { "Coalition" is a mea } \\
\text { T-statistics are show } \\
\text { The significance leve } \\
\text { The variance is calcu }\end{array}$ & $\begin{array}{l}\text { onsider as a basel } \\
\text { ation email. } \\
\text { lat assumes value } \\
\text { the coalition ideo } \\
\text { arenthesis below e } \\
\text { entified by asterisl } \\
\text { with the Huber-W }\end{array}$ & $\begin{array}{l}\text { e respective plac } \\
\text { ase the candidat } \\
\text { it assumes } 3 \text { val } \\
\text { stimated coeffici } \\
* 1 \% ; * * 5 \% ; * 10 \% \\
\text { sandwich estima }\end{array}$ & $\begin{array}{l}\text { and thus they mu } \\
\text { completed high- } \\
1 \text {, for left, } 0 \text { for } u \\
\text { correct for heter }\end{array}$ & $\begin{array}{l}\text { iterpreted as diffe } \\
+1 \text { for right. } \\
\text { sticity. }\end{array}$ \\
\hline
\end{tabular}

The multivariate analysis reveals that our experimental results concerning the answer rate to a swing voter are due to city-specific effects. When we control for city-specific effects the answer rate to senders that identified themselves as swing voters is not statistically different from the answer rate to those that did not provide any identification. The difference between the answer rate to the core voters and the placebo voters, instead, remains large and statistically significant. Thus, we conclude that in the 2008 Brazilian municipal elections candidates were systematically targeting core voters rather than voters 
that did not provide any identification. Regarding swing voters our model is silent, not identifying any statistical difference either between core and swing voters, or between swing and placebo voters.

If we focus on the core voter effect, combining the swing and the placebo treatment, we are able to identify a significantly positive difference between voters that identified themselves as core and the others. This difference is positive at around 8\%, and robust across specifications as can be observed in the first row of Table 4. Thus we can display some evidence that during the Brazilian municipal election of 2008 candidates were targeting more core voters, although it is difficult to argue that such a pattern is widespread and systematic.

Table 4. Multivariate Analysis, Brazil 2008, Municipal Elections

\begin{tabular}{|c|c|c|c|c|}
\hline \multicolumn{5}{|c|}{ Dep. Variable: receiving an answer } \\
\hline & LPr baseline & $\mathrm{LPr}$ & LPr & $\mathrm{LPr}$ \\
\hline Core & $\begin{array}{l}0.086^{* * * * *} \\
(2.83)\end{array}$ & $\begin{array}{l}0.075^{*} \\
(1.95)\end{array}$ & $\begin{array}{l}0.085^{* * *} \\
(2.25)\end{array}$ & $\begin{array}{l}0.083 \text { ** } \\
(2.21)\end{array}$ \\
\hline Past Supporter & $\begin{array}{l}0.014 \\
(0.39)\end{array}$ & $\begin{array}{l}0.039 \\
(0.87)\end{array}$ & $\begin{array}{l}0.044 \\
(1.0)\end{array}$ & $\begin{array}{l}0.043 \\
(0.97)\end{array}$ \\
\hline Past Opposer & $\begin{array}{l}0.053 \\
(1.40)\end{array}$ & $\begin{array}{l}0.07 \\
(1.48)\end{array}$ & $\begin{array}{l}0.065 \\
(1.37)\end{array}$ & $\begin{array}{l}0.065 \\
(1.35)\end{array}$ \\
\hline Male & $\begin{array}{l}-0.028 \\
(-1.0)\end{array}$ & $\begin{array}{l}-0.054 \\
(-1.56)\end{array}$ & $\begin{array}{l}-0.05 \\
(-1.43)\end{array}$ & $\begin{array}{l}-0.052 \\
(-1.51)\end{array}$ \\
\hline Small Entrepreneur & $\begin{array}{l}0.04 \\
(1.31)\end{array}$ & $\begin{array}{l}0.075^{*} \\
(1.81)\end{array}$ & $\begin{array}{l}0.075^{*} \\
(1.85)\end{array}$ & $\begin{array}{l}0.075^{*} \\
(1.86)\end{array}$ \\
\hline Education & & & $\begin{array}{l}0.008 \\
(0.02)\end{array}$ & $\begin{array}{l}-0.002 \\
(-0.06)\end{array}$ \\
\hline Candidate Age & & & $\begin{array}{l}-0.004 * * * * \\
(-2.44)\end{array}$ & $\begin{array}{l}-0.003 * \\
(-1.91)\end{array}$ \\
\hline Incumbent & & & $\begin{array}{l}-0.23 * * * * \\
(-4.36)\end{array}$ & $\begin{array}{l}-0.22 * * * * \\
(-4.18)\end{array}$ \\
\hline Coalition & & & & $\begin{array}{l}-0.038^{* * *} \\
(-2.05)\end{array}$ \\
\hline District Dummies & & Included & Included & Included \\
\hline Constant & ${ }^{0.227^{* * * * *}}$ & $\begin{array}{l}0.215^{* * * *} \\
(4.38)\end{array}$ & $\begin{array}{l}0.45 \% * * \\
(4.19)\end{array}$ & $\begin{array}{l}0.41 * * * * \\
(3.78)\end{array}$ \\
\hline Joint Test & $\begin{array}{l}\mathrm{F}(5 ; 1002)=2.45 \\
0.03\end{array}$ & $\begin{array}{l}F(5 ; 426)=1.98 \\
0.08\end{array}$ & $\begin{array}{l}\mathrm{F}(8 ; 426)=4.77 \\
0.00\end{array}$ & $\begin{array}{l}\mathrm{F}(9 ; 426)=4.98 \\
0.00\end{array}$ \\
\hline $\begin{array}{l}\text { Groups } \\
\mathrm{N}\end{array}$ & 1008 & $\begin{array}{l}427 \\
1008\end{array}$ & $\begin{array}{l}427 \\
1008\end{array}$ & $\begin{array}{l}427 \\
1008\end{array}$ \\
\hline $\begin{array}{l}\text { The first four coeffic } \\
\text { ences from the no id } \\
\text { "Education" is a dun } \\
\text { "Coalition" is a mea } \\
\text { T-statistics are show } \\
\text { The significance leve } \\
\text { The variance is calcu }\end{array}$ & $\begin{array}{l}\text { onsider as a basel } \\
\text { ation email. } \\
\text { lat assumes value } \\
\text { the coalition idec } \\
\text { arenthesis below } \\
\text { entified by asteris } \\
\text { with the Huber-W }\end{array}$ & $\begin{array}{l}\text { e respective pla } \\
\text { ase the candidat } \\
\text { it assumes } 3 \text { val } \\
\text { stimated coeffic } \\
* 1 \% ; * * 5 \% ; * 10 \% \\
\text { andwich estima }\end{array}$ & $\begin{array}{l}\text { and thus they mı } \\
\text { completed high- } \\
1 \text {, for left, } 0 \text { for } u \\
\text { correct for heter }\end{array}$ & $\begin{array}{l}\text { terpreted as diffe } \\
+1 \text { for right. } \\
\text { ticity. }\end{array}$ \\
\hline
\end{tabular}




\section{Discussion}

The experiment indicates that politicians at the municipal level in the Brazilian 2008 election cared equally about swing and core voters, but when we introduced pre-treatment controls and city fixed effects, the results changed (Tables 3 and 4). We obtained some evidence that Brazilian politicians were focusing more resources on core voters. However, it is difficult to argue that Brazilian politicians definitely target core voters based on these findings. Despite the fact that there might be a tendency for candidates to target core voters, only additional data can confirm such a hypothesis. It is in fact more likely that our results reinforce models that either consider two-dimensional strategies (Dunning and Stokes, 2008) in which the politicians have a more refined utility function that targets both core and swing voters at the same time, or an indiscriminate strategy resulting from an institutional setting that makes it more difficult for candidates to concentrate their resources in one type of voters.

As mentioned before, we hypothesize that the unique Brazilian institutional environment makes it more difficult for politicians to rely on voter loyalty. Carey and Shugart (1995) show that certain electoral rules create different incentives for personal vs. partisan votes. They argue that in open list systems there is an incentive for voters to seek personalistic strategies, while in closed list systems there are incentives to vote for partisan behavior. Therefore, it is possible that such patterns are affecting Brazilian majoritarian elections, but we cannot precisely argue in which direction the institutional characteristics of Brazilian elections are leading the results. However, we can argue that Brazilian candidates seem to have invested resources on core voters, while also targeting swing voters. Additionally, the indiscriminate way of answering to voters could portray difficulties in formulating efficient electoral strategies in a very complicated institutional setting.

Only further replications of the same experiment and in-depth interviews could clarify if Brazilian candidates truly target voters indiscriminately, and more importantly how the institutional settings affect the results. Additional replications of our design could elucidate potential behavioral patterns that correlate with specific types of election and different political environments. Although the impossibility of randomly assigning electoral rules will make it unfeasible to experimentally identify such effects, these replications could further the understanding of candidates' behavior and the possible effects of specific political environments ${ }^{1}$.

It is important to remember that although the overall response rate of candidates is considered low (around 30\%); this number shows some impressive and unexpected mobilization from candidates in targeting potential voters. A question that arises from this is, given that "talk is cheap" (and email even cheaper), why are politicians not responding 
to everyone? If they answer indiscriminately, why is the answer rate low since all emails received are potential voters? Do candidates care about communicating with constituents who have specific questions? Are there embedded costs in responding electronically to voters in Brazilian politics that prevent candidates from presenting higher response rates? These questions require further studies to be properly answered.

Submitted in May 2012

Accepted in March 2013

\section{References}

AMES, Barry and SMITH, Amy E. (2010), Knowing Left from Right: Left-Right Self-Identification and Ideology in Brazil, 2002-2006, Journal of Politics in Latin America, vol. 2, n ${ }^{\mathrm{o}} 3$, pp. 3-38.

AMORIM NETO, Octavio. (1998), Of Presidents, Parties, and Ministers: Cabinet Formation and Legislative Decision-Making under Separation of Powers, Unpublished PhD dissertation, University of California, San Diego.

ANSOLABEHERE, Stephen, and SNYDER Jr., James. (2006), Party Control of State Government and the Distribution of Public Expenditures, Scandinavian Journal of Economics, vol. 108, $\mathrm{n}^{\mathrm{o}} 4$, pp. 547-569.

CALVO, Ernesto, and MURILlO, Maria V. (2004), Who Delivers? Partisan Clients in the Argentine electoral market, American Journal of Political Science, vol. 48, nº 4, pp. 742-757.

CALVO, Ernesto, and MURILlO, Maria V. (2009), Selecting Clients: Partisan Networks and the Electoral Benefits of Targeted Distribution, Paper prepared for presentation at the Comparative Politics Workshop, Yale University, November.

CAREY, John, and SHUGART, Mathew S. (1995), Incentives to cultivate a personal vote: a rank ordering of electoral formulas, Electoral Studies, vol. 14, no 4, pp. 417-439.

CARREIRÃO, Yan, and KINZO, Maria Dalva. (2004), Partidos Políticos, Preferência Partidária e Decisão Eleitoral no Brasil (1989/2000), Revista Dados, vol. 47, nº 1, pp. 131-167.

CARREIRÃO, Yan. (2007), Relevant factors for the voting decision in the 2002 presidential election: an analysis of the ESEB (Brazilian Electoral Study) Data, Brazilian Political Science Review, vol. 1, $\mathrm{n}^{\circ}$ 1, pp. 70-101.

CASE, Anne. (2001), Election Goal and Income Redistribution: recent evidence from Albania, European Economic Review, vol. 45, nº 3, pp. 405-423.

COX, Gary, and McCUBBINS, Mathew. (1986), Electoral Politics as a Redistributive Game, The Journal of Politics, vol. 48, $\mathrm{n}^{\mathrm{o}}$ 2, pp. 370-389. 
COX, Gary. (2009), Swing Voters, Core Voters and Distributive Politics, In: Political Representation, edited by Ian Shapiro, Susan Stokes, Elisabeth Wood and Alexander S. Kirshner. New York: Cambridge University Press.

DAHLBERG, Matz, and JOHANSSON, Eva. (2002), On the Vote-purchasing Behavior of Incumbents Governments, American Political Science Review, vol. 96, n 2, pp. 27-40.

DIAZ-CAYEROS, Alberto. (2008), Electoral Risk and redistributive politics in Mexico and the US, Studies in Comparative International Development, vol. 43, n² 2, pp. 129-150.

DUNNING, Thad, and STOKES, Susan. (2008), Persuasion vs. Mobilization: When Do Clientelist Parties Buy Votes or Turnout?, Paper presented at the 66th Midwest Political Science Association Annual National Conference, Chicago, IL.

FIRTH, Michael. (1981), Racial Discrimination in the British Labor Market, Industrial and Labor Relations Review, vol. 34, $\mathrm{n}^{\circ}$ 2, pp. 265-272.

GERBER, Alan; GREEN, Donald, and KAPLAN, Edward. (2004), The Illusion of Learning from Observational Research, In: Problems and Methods in the Study of Politics, edited by Ian Shapiro, Roger Smith, and Tarek Massoud. New York: Cambridge University Press.

GERBER, Alan, and GREEN, Donald. (2012), Field Experiments: design, analysis, and interpretation. New York: W.W. Norton \& Company.

GREEN, Donald. (2009), Regression Adjustments to Experimental Data: Do David Freedman's Concerns Apply to Political Science?, Paper presented at the 26th annual meeting of the Society for Political Methodology, Yale University, July 23-25. <http://www.polmeth.wustl. edu/media/Paper/Green -- Regression Adjustments to Experimental Data 070809.pdf >.

LINDBECK, Assar, and WEIBULL, Jorgen. (1987), Balanced-budget Redistribution as the Outcome of Political Competition, Public Choice, $\mathrm{n}^{\circ}$ 52, pp. 273-297.

MAGALONI, Beatriz; DIAZ-CAYEROS, Alberto, and ESTEVEZ, Frederico. (2008), The Core Voter Model: evidence from Mexico, Paper presented at 104th American Political Science Association Meeting, Boston, MA.

NICHTER, Simeon. (2008), Vote Buying or Vote Turnout Buying? Machine Politics and the Secret Ballot, American Political Science Review, vol. 102, nº1, pp. 19-31.

NICOLAU, Jairo. (1996), Multipartidarismo e Democracia: Um Estudo sobre o Sistema Partidário Brasileiro (1985-94). Rio de Janeiro: Fundação Getulio Vargas Editora.

NICOLAU, Jairo. (2002), Como Controlar o Representante? Considerações sobre as eleições para a Câmara dos Deputados, Revista Dados, vol. 45, n² 2, pp. 219-236.

OREOPOULOS, Philip. (2009), Why Do Skilled Immigrants Struggle in the Labor Market? A Field Experiment with Six Thousand Resumes, NBER Working Paper Series $\mathrm{n}^{\circ} 15036$, National Bureau of Economic Research, Cambridge, <http://www.nber.org/papers/w15036.pdf>

SAMUELS, David, and ZUCCO, Cesar. (2012), The Power of Partisanship in Brazil: Evidence from Survey Experiments, Working paper, <http://cepesp.foles.wordpress.com/2013/03/ samuels-zucco-rr.pdf $>$. 
SCHADY, Norbert. (2000), The Political Economy of Expenditure by the Peruvian Social Fund (FONCODES), American Political Science Review, vol. 94, n 2, pp. 289-304.

SPADA, Paolo. (2007), Political Competition, Candidate Rationality and Selective Perception: a Field Experiment of Italian 2006 National Elections, Paper presented at the 65th Midwest Political Science Association Annual National Conference, Chicago, IL.

SPADA, Paolo, GUIMARÃES, Feliciano S, CEPALUNI, Gabriel, and KERN, Holger. (2010), On Politicians' Office-seeking behavior: evidence from a pair of field experiments in Brazil, Paper presented at the 68th Midwest Political Science Association Annual National Conference, Chicago, IL.

STOKES, Susan. (2005), Perverse Accountability: a formal model of machine politics with evidence from Argentina, American Political Science Review, vol. 99, n 3, pp. 315-326.

WEICHSELBAUMER, Doris. (2003), Sexual Orientation Discrimination in Hiring, Labour Economics, vol. 10, no 6, pp. 629-642.

\section{Notes}

1 We performed a similar experiment in the 2010 national election. Although the national election has a rather different institutional setting compared to the municipal election, we found no differences in answering rates between core and swing voters. It is important to remember, however, that the 2010 experiment was also testing other factors such as race and gender that might have biased the results (Spada, Guimarães, Cepaluni and Kern, 2010). 